\title{
Employment and earnings of California farmworkers in 2015
}

\author{
A review of wage data from agricultural employers suggests that most California farmworkers were \\ employed for less than a full year in 2015.
}

by Philip Martin, Brandon Hooker and Marc Stockton

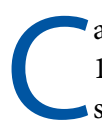

alifornia has led the nation in farm sales since 1950, when Los Angeles County had more farm sales than any other county in the United States, largely because of specialization in the production of high-value fruit, nut and vegetable $(\mathrm{FVH})$ crops. California's farm sales in 2015 were $\$ 47$ billion, including $\$ 18$ billion from the sale of fruits and nuts, $\$ 9$ billion from vegetables and melons, and $\$ 5$ billion from horticultural specialties such as floriculture, nurseries and mushrooms. That is, $\$ 32$ billion, or two-thirds, of farm sales were from these FVH crops. The leading farm counties, Tulare, Kern and Fresno, each had farm sales of almost $\$ 7$ billion in 2015 (CDFA 2017).

The production of many fruits and vegetables is labor-intensive, meaning that labor represents $20 \%$ to $40 \%$ of production costs for table grapes, strawberries and other commodities.

Average employment of 421,300 farmworkers in 2015 represents 12 monthly snapshots of persons on the payroll during the pay period that includes the 12th of the month. However, total wages of $\$ 12.8$ billion are all wages paid to all workers, including those who were employed at other times during the month (but

\section{Abstract}

The average employment of hired workers in California agriculture (NAICS 11) rose over 10\% between 2005 and 2015, when some 16,400 agricultural establishments hired an average 421,300 workers who were paid a total of $\$ 12.8$ billion, which was $27 \%$ of the state's $\$ 47$ billion in farm sales. This means that a full-time equivalent (FTE) employee would earn $\$ 30,300$, implying an hourly wage of $\$ 14.55$ for 2,080 hours of work. We extracted all Social Security numbers reported by California agricultural establishments and found that the average annual pay received by the 848,000 workers who had at least one job on California farms was $\$ 20,500$ in 2015 , two-thirds of the average annual wage of an FTE worker, reflecting some combination of lower wages and less than full-year work.

not during the pay period that includes the 12 th of the month) and those who earned wages from nonfarm employers.

A worker who was employed 2,080 hours the number of hours California's Employment Development Department (EDD) considers full-time
Online: https://doi.org/10.3733/ ca.2017a0043

Published online

November 16, 2017

Farmworkers harvest lettuce at Lakeside Organic Gardens in Watsonville, Santa Cruz County. In 2015, twothirds of California's farm sales were from fruit, nut and vegetable crops, many of which are labor intensive. 
and full-year employment - would earn an average annual pay of $\$ 30,300$, which prompted the Los Angeles Times to ask why, despite implied hourly wages of almost $\$ 15$ per hour, U.S.-born workers reject farm jobs (Kitroeff and Mohan 2017). The answer is that few farmworkers are employed year-round; many are employed fewer than 2,080 hours a year. In 2015, the average earnings of all workers with at least one farm job was $\$ 20,500$.

EDD does not collect hours of work data from employers who are paying unemployment insurance taxes, but does collect the earnings and employment data that we use in this article. The National Agricultural Workers Survey (NAWS) collects hours of work data from California crop workers, and found that they were employed an average of 47 hours during the week before they were interviewed in 2015-16. American Community Survey (ACS) data, also collected from workers, shows that both crop and livestock workers were employed slightly more than 40 hours a week. The NAWS and ACS do not collect data on annual hours worked. However, if workers averaged more than 40 hours a week over 52 weeks, average hourly earnings would be lower than $\$ 15$.

Nonsupervisory production workers do most of the work on the state's largest farms that produce laborintensive FVH crops. About $90 \%$ of California crop workers were born in Mexico, and 60\% are unauthorized, according to the NAWS, which is 10 percentage points higher than the U.S. average of $50 \%$ unauthorized crop workers (Carroll 2017). The reason for more unauthorized workers in California is that it has a higher share of foreign-born workers: most foreignborn workers are unauthorized, and California's $90 \%$ share of foreign-born crop workers exceeds the $60 \%$

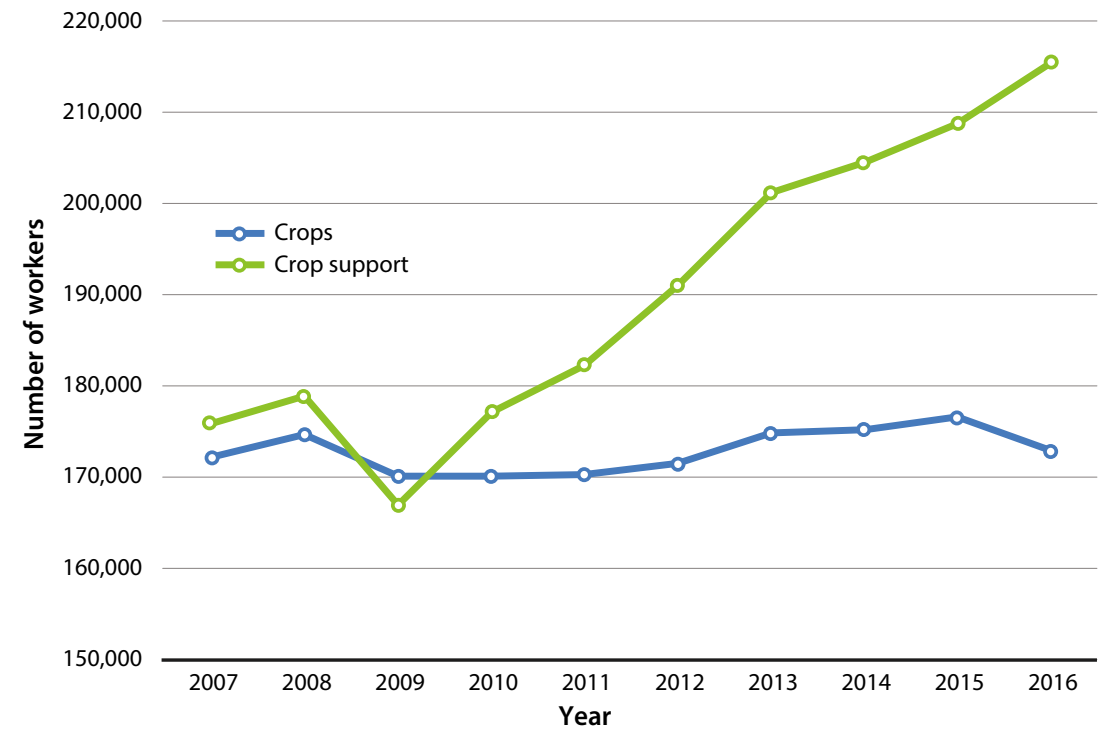

Fig. 1. Average California crop and crop support employment, 2007-2016. Crop employment refers to workers hired directly by farmers, and crop support refers to nonfarm employers that bring workers to farms, such as farm labor contractors. foreign-born share in the rest of the United States. A slowdown in unauthorized migration can put upward pressure on wages.

The dominance of labor-intensive crops in California, and the Trump administration's efforts to step up border and interior enforcement, has increased interest in the availability of farmworkers. EDD regularly obtains data on farmworkers and wages paid when employers pay unemployment insurance taxes. Employers who pay more than $\$ 100$ in quarterly wages are required to register with the EDD and pay taxes of up to $6 \%$ on the first $\$ 7,000$ of each worker's earnings to cover the cost of unemployment insurance benefits for laid-off workers.

We extracted all Social Security numbers (SSNs) reported by California agricultural employers (NAICS 11) in 2015 and tabulated all of the farm and nonfarm jobs and earnings of these farmworkers. This allowed us to assign workers who had more than one job to their primary commodity, the North American Industry Classification System (NAICS, www.census. gov/eos/www/naics/) code of the employer(s), and the county where they had their maximum earnings.

\section{Average employment and farmworkers}

Figure 1 shows average employment in California crop agriculture since 2007. Average employment rose over $10 \%$, but there was an important change in crop agriculture after 2007, when nonfarm crop support employers - those who bring workers to crop farms, such as farm labor contractors (FLCs) - began to bring more workers to farms than were hired directly by crop farmers. There are several reasons why farmers may turn to FLCs for workers, including the ability of FLCs to assemble crews of workers at lower cost than farmers who hire workers directly.

According to EDD data, over the past decade crop farmers (NAICS 111) have hired a few more workers directly, animal agriculture (NAICS 112) has had stable average employment, and there has been a sharp increase in crop support employment (1151), most of it with FLCs. The average employment of crop support establishments has been rising by 10,000 a year, so that in 2016 nonfarm crop support firms brought an average 215,000 full-time equivalent (FTE) workers to crop farms, more than the average 173,000 FTE workers that these farms hired directly (fig. 1). Average FTE employment in animal agriculture has been stable at about 29,000 , while animal support employment fell slightly.

The total number of farmworkers employed sometime during the year is larger than average employment because of seasonality and turnover. In 2015, employment peaked at 475,000 in July and reached a low of 350,000 in December, guaranteeing at least 475,000 unique farmworkers. The actual number of workers is higher because of turnover: some workers do only a few days or weeks of farm work and quit, and workers 
employed in the Coachella and Imperial Valleys during the winter and spring rarely migrate to the San Joaquin Valley for the summer harvest, so different workers are required in different areas.

Our analysis captures all workers hired by farm employers. After making adjustments for what appeared to be false or shared SSNs, in 2015 there were 848,000 unique SSNs reported by agricultural establishments, twice the average FTE employment of 421,000 (fig. 2). This suggests two workers per FTE job, a ratio that has been stable over the past decade. Average FTE employment and the number of unique farmworkers each rose 10\% between 2007 and 2015 .

\section{FTE employment, average earnings}

The average annual pay of FTE agricultural workers varies by commodity. In 2015, the average annual pay of a directly hired FTE crop worker was $\$ 32,500$, that of an FTE animal worker was $\$ 35,900$, and that of an FTE crop support worker was $\$ 27,500$.

Table 1 presents data on the number of establishments, average employment and average annual pay for California commodities where average employment was at least 10,000 employees. The four crop categories in the table accounted for almost all establishments and average employment in the NAICS code for crops (111); dairies accounted for half of NAICS 112 animal employer establishments and two-thirds of animal employment and total wages. The four crop

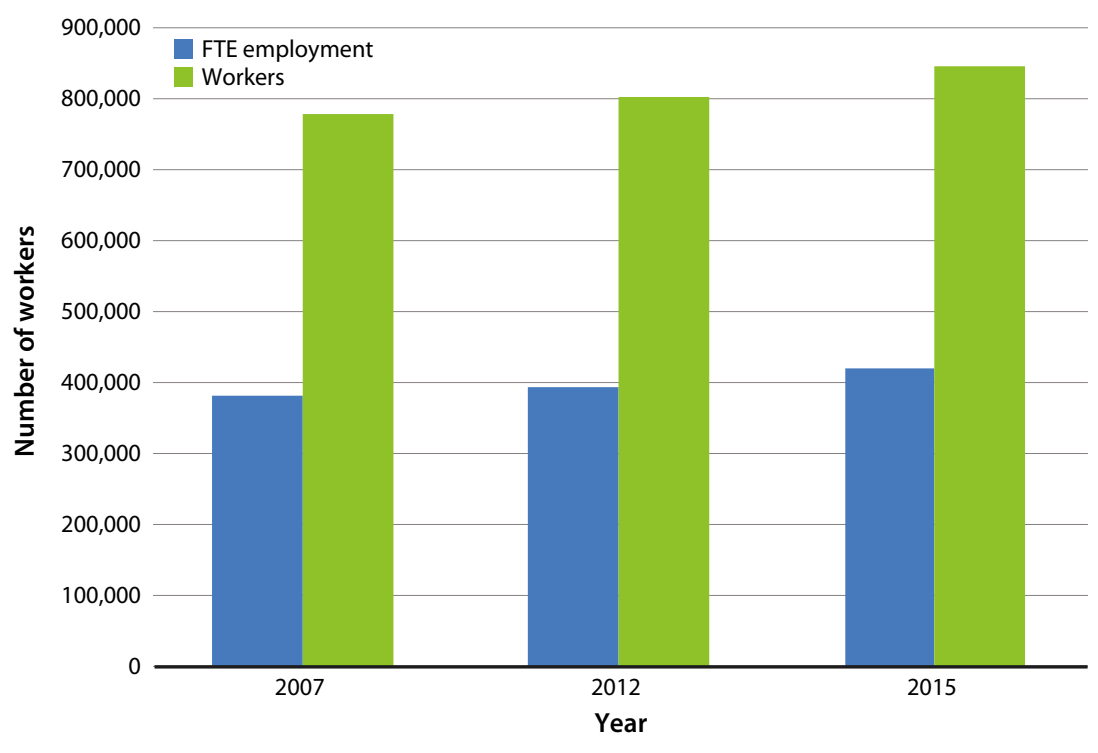

Fig. 2. Average FTE employment and unique farmworkers: 2007, 2012 and 2015.

support services listed under NAICS 1151 in the table accounted for almost all of the establishments, average employment, and total wages in the crop support category.

Farm employment is concentrated in a few commodities. Fruits and nuts accounted for $57 \%$ of average direct-hire crop employment in 2015, dairy for $64 \%$ of direct-hire animal employment, and FLCs for

TABLE 1. FTE and primary worker average annual pay, 2015

\begin{tabular}{|c|c|c|c|c|c|c|}
\hline Code & Commodity & $\begin{array}{l}\text { No. } \\
\text { establishments }\end{array}$ & $\begin{array}{l}\text { Average no. } \\
\text { employees }\end{array}$ & $\begin{array}{l}\text { Total wages } \\
(\$ 000)\end{array}$ & $\begin{array}{l}\text { Average } \\
\text { annual pay }\end{array}$ & $\begin{array}{l}\text { Hourly } \\
\text { earnings }\end{array}$ \\
\hline NAICS 11 & Agriculture, forestry, fish & 16,408 & 421,288 & $12,757,819$ & 30,283 & 14.56 \\
\hline NAICS $111^{*}$ & Crop production & 9,567 & 176,537 & $5,734,489$ & 32,483 & 15.62 \\
\hline NAICS1112 & Vegetables and melons & 927 & 34,010 & $1,256,717$ & 36,951 & 17.76 \\
\hline NAICS1113 & Fruits and nuts & 5,731 & 100,512 & $3,019,122$ & 30,038 & 14.44 \\
\hline NAICS1114 & Greenhouse & 997 & 27,317 & 910,934 & 33,347 & 16.03 \\
\hline NAICS1119 & Other crops & 1,209 & 11,269 & 415,618 & 36,882 & 17.73 \\
\hline NAICS 112 & Animal production & 2,534 & 28,496 & $1,021,973$ & 35,864 & 17.24 \\
\hline NAICS1121 & Cattle \& ranch & 1,867 & 22,885 & 819,089 & 35,792 & 17.21 \\
\hline 11212 & Dairy cattle & 1,187 & 18,057 & 633,899 & 35,105 & 16.88 \\
\hline NAICS 115 & $\begin{array}{l}\text { Support activities for forestry \& } \\
\text { agriculture }\end{array}$ & 3,810 & 213,178 & $5,856,656$ & 27,473 & 13.21 \\
\hline NAICS 1151 & Support activities for crop production & 3,028 & 208,857 & $5,685,346$ & 27,221 & 13.09 \\
\hline 115112 & Soil preparation & 642 & 10,347 & 387,768 & 37,476 & 18.02 \\
\hline 115114 & Postharvest crop activities & 559 & 38,578 & $1,471,818$ & 38,152 & 18.34 \\
\hline 115115 & Farm labor contractors & 1,130 & 141,439 & $3,177,222$ & 22,464 & 10.80 \\
\hline 115116 & Farm management services & 385 & 11,420 & 418,194 & 36,619 & 17.61 \\
\hline
\end{tabular}

Source: California EDD analysis of unemployment insurance payroll tax data.

NAICS codes add digits to reflect specialization, so that 2-digit NAICS 11 is agriculture, 3-digit NAICS 111 is crops, and 4-digit NAICS 1113 is fruits and nuts. NAICS 115 is support activities for agriculture, that is, nonfarm employers who bring workers to farms to perform specific activities.

* Bold indicates 4-digit umbrella categories for the more detailed commodities below. 
two-thirds of average crop support employment. For a FTE worker, the implied average hourly earnings ranged from a low of $\$ 10.80$ for FLC employees to $\$ 18.34$ for other post-harvest activities such as cooling and cleaning crops after they are harvested. California's minimum wage was \$9 per hour in 2015.

Since we have data on all workers who were employed in a commodity, we can calculate the difference between the earnings of an FTE worker and the earnings of an average worker. We assigned farmworkers to the commodity or NAICS code in which they had their highest earnings, and found that 705,000 workers had their maximum earnings from a farm employer; we call these workers primary farmworkers. Table 2 shows that these primary farmworkers averaged $\$ 17,434$, or $58 \%$, of what an FTE worker employed in agriculture would have earned.

We assigned the 705,000 primary farmworkers to the NAICS code or commodity in which they had their maximum earnings in order to determine what share of FTE earnings in that commodity a typical worker received; for over 100,000 farmworkers, this was a nonfarm NAICS or employer. Primary crop workers were those whose maximum earnings were from employers with NAICS 111, and they averaged $\$ 21,467$, two-thirds of what an FTE crop worker would have earned (table 2). Those whose maximum earnings were in greenhouses and nurseries earned $84 \%$ of FTE earnings in this commodity, while those whose maximum earnings were in more seasonal fruits and nuts earned $57 \%$ as much.
Primary workers in animal agriculture earned $86 \%$ of what an FTE animal worker would have earned, and dairy workers, who were almost two-thirds of primary animal agriculture employment, earned $87 \%$ of what an FTE dairy worker would have earned (table 2), likely reflecting more hours of work during the year.

Support service workers outside of crops earned almost as much as an FTE worker, but not crop support workers, who earned only half of what an FTE crop support worker would receive. The seasonality and turnover in crop support means that primary workers employed by FLCs, the largest group of workers, earned only $44 \%$ as much as an FTE worker employed by FLCs (table 2).

Since the implied hourly wage for an FTE worker employed by FLCs was only slightly above the state's minimum wage, the low average earnings of primary FLC employees must arise from fewer hours of work. A worker employed 1,000 hours at $\$ 9.86$ an hour would have earned the average amount of a primary FLC employee in $2015, \$ 9,878$.

Most primary agricultural workers, $70 \%$, had only one job in 2015; this was a farm job, since having a farm job was necessary to be selected. Over $85 \%$ of animal workers employed in sheep, hogs and poultry had just one job in 2015, but less than $60 \%$ of workers who were employed in strawberries and vegetables had only one job. About $70 \%$ of primary FLC employees had one job in 2015.

A quarter of farmworkers, some 223,000, had two or more jobs, and $18 \%$ had three or more jobs. Half of

TABLE 2. Primary worker average annual pay, 2015

\begin{tabular}{|c|c|c|c|c|}
\hline Commodity & No. primary workers & $\begin{array}{c}\text { Primary worker } \\
\text { earnings } \\
\quad \$ \text { mil }\end{array}$ & $\begin{array}{c}\text { Average primary } \\
\text { worker earnings } \\
\qquad\end{array}$ & $\begin{array}{c}\text { Average primary / average } \\
\text { FTE earnings }\end{array}$ \\
\hline Agriculture, forestry, fish & 705,000 & $12,288.00$ & 17,434 & $58 \%$ \\
\hline Crop production & 260,000 & $5,553.90$ & 21,467 & $66 \%$ \\
\hline Vegetables and melons & 48,500 & $1,232.30$ & 25,818 & $68 \%$ \\
\hline Fruits and nuts & 154,000 & $2,850.00$ & 17,008 & $57 \%$ \\
\hline Greenhouse & 32,700 & 981.1 & 30,007 & $84 \%$ \\
\hline Other crops & 18,000 & 452.1 & 25,117 & $68 \%$ \\
\hline Animal production & 32,700 & 983 & 30,061 & $86 \%$ \\
\hline Cattle \& ranch & 25,800 & 788.7 & 30,389 & $85 \%$ \\
\hline Dairy cattle & 20,234 & 614,889 & 30,389 & $87 \%$ \\
\hline Support activities for agriculture \& forestry & 408,670 & $5,602.30$ & 13,709 & $50 \%$ \\
\hline Support activities for crop production & 403,000 & $5,440.00$ & 13,498 & $50 \%$ \\
\hline Soil prep & 17,900 & 358.4 & 19,971 & $53 \%$ \\
\hline Postharvest crop activities & 62,310 & $1,549.00$ & 24,859 & $65 \%$ \\
\hline Farm labor contractors & 293,900 & 2903.1 & 9,878 & $44 \%$ \\
\hline Farm management services & 16,800 & 407.2 & 24,307 & $66 \%$ \\
\hline
\end{tabular}

Source: EDD analysis of unemployment insurance payroll tax data. 
the 51,500 primary FLC workers who had two or more jobs in 2015 had one farm and one nonfarm job, while two-thirds of the 11,300 post-harvest crop support workers had one farm and one nonfarm job. Half of the primary FLC workers with two or more jobs got at least $75 \%$ of their annual pay from FLCs, just as half of the dairy workers with two or more jobs got at least

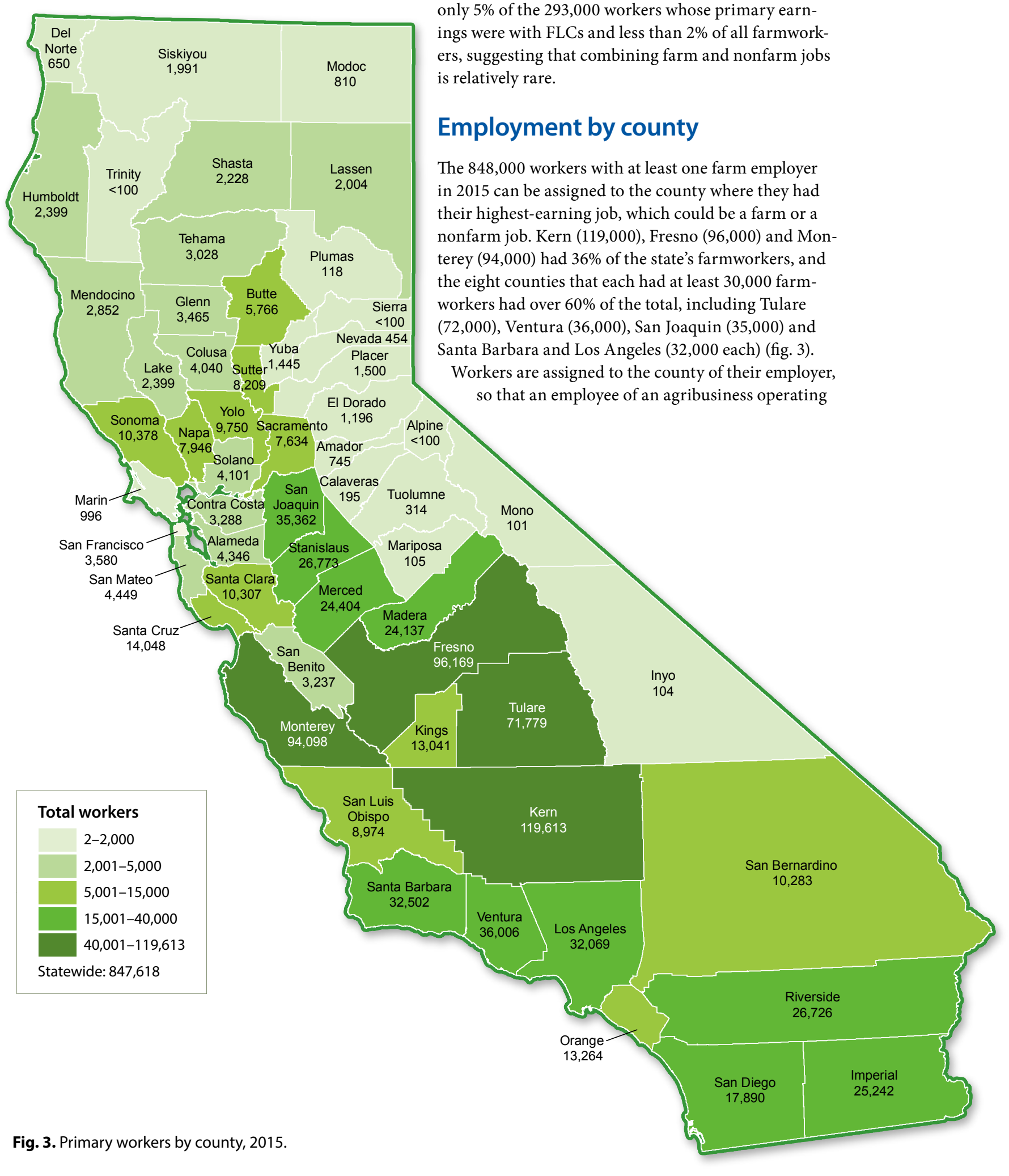


